\title{
DIE ONTWIKKELING VAN DIE MENSLIKE BEWUSSYN: DIE POSTMODERNE VRAAG NA GOD
}

\author{
Author: \\ Ignatius (Naas) W. Ferreira
}

\section{Affiliation:}

${ }^{1}$ Departement Praktiese

Teologie, Universiteit van

Pretoria, Suid-Afrika

\section{Correspondence to:}

Ignatius (Naas) W. Ferreira

e-mail:

naasf@mweb.co.za

\section{Postal address:}

Posbus 12402, Elspark 1418, Suid-Afrika

\section{Keywords:}

godsdienstige naturalisme; teïsme; panenteïsme; sekulêre paradigma; geloof en etiek

\section{Dates:}

Received: 23 Apr. 2009 Accepted: 25 May 2009

Published: 30 Sept. 2009

How to cite this article: Ferreira, I.W., 2009, ‘Die ontwikkeling van die menslike bewussyn: Die postmoderne vraag na God', HTS Teologiese Studies/Theological Studies 65(1), Art. \#178, 6 pages. DOI: 10.4102/hts.v65i1.178

\section{This article is available}

http://www.hts.org.za

Note:

Hierdie artikel is 'n verwerking van ' $n$ deel van I.W. Ferreira se MThverhandeling getiteld 'Die relevansie van Ken Wilber se integrale ontwikkelingsteorie vir die pastoraat' onder studieleiding van prof. dr Yolanda Dreyer, voorgelê en aanvaar in Augustus 2008 deur die Departement Praktiese Teologie, Fakulteit Teologie, Universiteit van Pretoria.

(c) 2009. The Authors. Licensee: OpenJournals Publishing. This work is licensed under the Creative Commons Attribution License.

\section{ABSTRACT}

The development of the human consciousness: The postmodern quest for God This articlecritically reflects upon 'emerging Christians' - those who have departed from a premodern (theistic) and modernist (secular) view of reality, and have rather embraced postmodernity in response to the cognitive dissonance they experience due to a clash of epistemological paradigms. The article discusses psychological theories on the development of human consciousness, and describes seven levels or stages of such development, namely the archaic, magical, mythological, rational, pluralistic, holistic and transpersonal levels. The article focuses on Ken Wilber's integral psychological theory, better known as AQAL (All Quadrants, All Levels and All Lines), which also covers the internal and external dimensions of human consciousness, including an integral view on the so-called 'states of human consciousness'. In doing so, the article aims to contribute to that aspect of pastoral care that focuses on psychological theory.

\section{INLEIDING: WAT IS DIE VRAAG?}

Die kerklike pastoraat is in ' $\mathrm{n}$ dilemma - dit word van sowel binne as buite bedreig: Terwyl die kerklike teologie op 'n Bybelse teïsme konsentreer, is daar Christene wat nie meer met die tradisionele begrip van die Bybel, of die kerklike praktyk van Sondag-aanbidding van' $n$ transendentale God gemaklik voel nie (kyk Avis 2003:50-81; Riggs 2003:9). Terselfdertyd voel tradisionele Christene ontuis in 'n sekulêre samelewing waarin hulle geloof en etiek misken word (Norman 2003:ix; Weiland 1972:17-42). Hoewel die tradisionele kerklike teïsme standvastig lyk, kom dit tog voor of daar wél Christene is wat die tradisionele teologie van sowel binne as buite bevraagteken. Tradisionele Christene voel dat die wêreld die kerk deur ateïsme en die wetenskap bedreig. Catherine Keller, ' $n$ prosesteoloog, vat dié dilemma soos volg saam:

Nothing more surely characterizes our era, which we might as well call postmodern, than awareness of multiplicity...[T]his plurality sends some running back to the security of some absolute: nulla salvus extra ecclesiam - "No salvation outside of the church." And it dissipates others in a global marketplace of options.

(Keller 2008:21)

In The God problem: Alternatives to fundamentalism, met verwysing na Robert W. Funk, vra Nigel Leaves (2006:5) die vraag 'What does "God" mean in the twenty-first century?', en bespreek dan die moontlike antwoorde hierop aan die hand van ' $n$ aantal beskouinge oor God. Leaves wys vier belangrike sienings van God uit. Die eerste is panenteïsme, soos verwoord deur biskop John Shelby Spong. Panenteïsme verwerp die tradisionele bonatuurlike teïsme, en beskou God eerder as 'n allesomvattende Gees wat nie van die wêreld verwyderd is nie, maar tog bo die wêreld uitstyg. Die Gees is in alles, en alles is in die Gees, maar die Gees is groter as alles. Die tweede siening van God is die nie-realisme van Don Cupitt en Lloyd Geering wat albei, hoewel in verskillende wêrelddele, tot die volgende gevolgtrekking kom:

...the word "God" should be stripped of its supernatural content...[P]eople should get over the realist idea of an actual personal being who created and still sustains the Universe...Cupitt and Geering do not nullify Christian doctrines,...but translate them into rules of life.

(Leaves 2006:6, 7, 8)

Die derde Godsbeskouing staan as voetsoolvlakspiritualiteit ('grassroots spirituality') bekend, en spruit uit gewone mense se soeke na alternatiewe. Die vierde moontlikheid is godsdienstige naturalisme wat mense aanmoedig om die aarde as heilig te beskou. Al vier dié sienings oor die betekenis van God in die $21^{\mathrm{e}}$ eeu maak deel uit van Keller se 'global marketplace of options'. Die probleem is dat dit voorkom of gelowiges slegs tussen die tradisionele teïsme en die pluralisme van postmoderniteit, waarvan Leaves se vier alternatiewe deel uitmaak, kan kies. Hierdie artikel sal toon dat teïsme en pluralisme nie keuses is nie, maar wel deel van die ontwikkeling van die menslike bewussyn; ${ }^{1}$ dat daar veelvoudige vlakke van ontwikkeling is, en dat veelvoudige beskouings oor God dus moontlik is.

Die keuse tussen teïsme en pluralisme kom in 'n onlangse PhD-studie, 'Pastors as gewonde genesers: Emosionele intelligensie en pastoraat', aan die orde waar Philip Nolte (2007:5), ' $n$ predikant van die Nederduitsch Hervormde Kerk, daarop wys dat pastors 'n kognitiewe dissonansie beleef as gevolg van ' $n$ verskuiwing of ontwikkeling van ' $n$ moderne na ' $n$ postmoderne begrip van die werklikheid. In sy ondersoek na die spanning tussen dié twee paradigmas, sê Nolte (2007:9): 'Baie lidmate van die Christelike geloofstradisie bevind hulle binne die vroeë, tradisionele paradigma, terwyl baie ander hulleself binne die nuwe opkomende paradigma bevind.' Nolte noem dat diegene wat hulle in die opkomende paradigma bevind net frustrasie in die kerklike tradisie ervaar. Nolte (2007:10-12), benoem die eienskappe van die tradisionele paradigma soos volg:

Wanneer daar in dié studie na die begrip 'menslike bewussyn' ("human consciousness") verwys word, dra dit nie dieselfde betekenis as die onveranderlike, ewige Bewussyn ("Consciousness") nie. Sommige skrywers, onder andere Peter F. Dziuban (2006), gebruik 'Bewussyn' as 'n metafoor vir wat Christene as God sou beskryf. 'Menslike bewussyn' verwys na die mens se begrip van die werklikheid, maar is terselfdertyd meer as bloot ' $n$ kognitiewe funksie. Dit is wanneer die menslike bewussyn welbewus een met die Bewussyn word dat die mens die hoogste ideaal bereik. 
- Die Bybel neem 'n sentrale plek in en word as 'God se woord' beskou.

- Die belydenisse en belydenisgeskrifte speel 'n belangrike rol, en word as ' $n$ samevatting van die 'waarhede' van die Bybel geag.

- Geloof word in 'n groot mate as instemming met leerstellings oor God en die Bybel beskou.

- Ten spyte daarvan dat hierdie paradigma God se 'gratis' liefde en genade vir mense beklemtoon, is daar tóg ' $n$ onderliggende patroon van prestasie en beloning in die logika daarvan te bespeur.

Hierteenoor som Nolte $(2007: 12,11,12,13$, 14) die opkomende paradigma soos volg op:

- Die Bybel word as die produk van 'n lang historiese proses beskou, en besin onder andere oor antieke mense se oortuigings oor God, hulle godsdiens- en wêreldbeskouing, die wyse waarop die gemeenskap ingerig en georden word, sowel as verhoudings tussen mense, dinge en plekke.

- Aanhangers van dié paradigma beskou die Bybel metafories, en erken dat die Bybelse verhale wáár kan wees sonder om histories korrek te wees. Die waarde van die Bybel lê dus in die betekenis wat die Bybelse verhale vir mense het.

- Die Bybel word as heilige geskrifte beskou wat die funksie en status daarvan, maar nie die ontstaan daarvan nie, betref.

- Christene beskou hulle lewens as ' $n$ proses van verhoudings en transformasie, en nie as die nakoming van sekere voorskrifte nie.

- Die paradigma erken religieuse pluraliteit, en neem dit ernstig op.

Nolte $(2007: 18,22)$ beskou die kerklike tradisie as 'n struikelblok en die tradisionele Skrifgesag as ' $n$ probleem vir die postmoderne Christen, en bied emosionele intelligensie aan as oplossing vir diegene wat hy 'gewonde pastors' noem. Hierdie verwonding is die gevolg van die verskuiwing van ' $n$ moderne na ' $n$ postmoderne paradigma, omdat postmodernisme baie van die sekerhede van die moderne era gerelativeer het. Nolte omskryf dié verwonding soos volg:

Die verlamming wat pastors as gevolg van die verskuiwing van die moderne na die postmoderne paradigma beleef, kan as kognitiewe dissonansie omskryf word. Dit is'n aangeleentheid wat met 'kennis' verband hou wat nie in pas is met die realiteite in die lewe waarmee mense daagliks moet rekening hou nie.

(Nolte 2007:7)

Buiten bogenoemde aspekte, opper Nolte nóg twee sake wat vir hierdie artikel van belang is, naamlik '...'n nuwe paradigma is nie ' $n$ kombinasie uit vorige en nuwe paradigmas nie, maar ' $n$ breuk met interpreterende raamwerke van vroeër' (Nolte 2007:15), en 'Emosionele intelligensie kan kernagtig beskryf word as mense se vermoë om van hulle eie emosies, asook die emosies van ander persone, bewus te raak en dit sinvol en verantwoordelik te integreer en bestudeer' (Nolte 2007:17).

Paul Avis (2003:vii), die sekretaris-generaal van die Anglikaanse Kerk se Raad vir Christelike Eenheid, beskou die drieledigheid van die missio Dei van die kerk as die onderliggende aspek van die bediening aan Christene buite die kerk. Hierdie drieledige sending, wat in Matteus 28:16-20 voorkom, is om dissipels van mense te maak, om mense te doop, en om hulle te leer. Volgens hom is algemene godsdiens ('common religion') die manier om mense terug in die kerk te kry. Slegs weens pastorale betrokkenheid en die bou van vertroue tussen die kerk en die individu sal mense na die kerk terugkeer; nie weens hoogdrawende prediking nie. Avis stel dit soos volg:

But the real work of building trust and establishing rapport - the sine qua non of effective mission and ministry - can only be done piecemeal, "on the ground", in thousands of particular situations, when commitment is sustained over time.

(Avis 2003:ix) Hy beskryf algemene godsdiens as ' $n$ brug om mense na die gemeenskap van gelowiges terug te lok. Avis (2003:136) erken voorts dat die ontwikkeling van gelowiges deur verskeie stadia gaan, en noem dat dit ' $n$ sakramentele karakter het teenoor die sekulêre wêreld se beheptheid met ekonomiese vooruitgang. Hy beskryf dit soos volg:

Instead of the soul making its Christian journey from baptism and confirmation, through matrimony, to final passing over the threshold of death accompanied by Christian burial rites that sanctify our mortality, we have the secular self following a stereotyped life-course dedicated by society-wide economic and political institutions.

(Avis 2003:37)

Tog beweer Avis (2003:137) dat die sekulêre paradigma die individu respekteer, maar nie die nodige Christelike deernis en ondersteuning bied nie. Volgens hom kan die doop, huwelik en die laaste sakrament weer die skakels word om diegene buite die kerk aan die pastoraat, en dus die evangelie, bloot te stel. Robert Price (2003:3-8), 'n dosent in Filosofie en Godsdienswetenskap aan die Johnston Community College in Smithfield, Noord-Carolina, merk in sy artikel

The future of religion' soos volg op: '...the world is moving rapidly towards a state in which virtually everyone will have no choice but to think for himself or herself in religious matters.

Price (2003:3)

Verder verwys Price (2003:3) na Peter Berger wat ontwikkeling in kultuur en godsdiens as ' $\mathrm{n}$ noodwendigheid beskou namate volke met mekaar in aanraking kom. Afgesonderde gemeenskappe is geneig om hulle godsdiens en kultuur as die enigste waarheid te beskou. Die blootstelling aan ander groepe, en dus die verbreding van kennis en insig, vind egter nie sonder probleme plaas nie. Die Jodedom het byna voor die Griekse Dionysus-kultus geswig. Price (2003:4) wys met behulp van die filosoof Francois Lyotard se werk, The postmodern condition, op die 'hoofnarratief' waarvolgens elke volk leef. Israel se hoofnarratief is die verhale van Abraham, die uittog uit Egipte, die monargie, die ballingskap en die herstel. Dit is wanneer dié hoofnarratief bedreig en afgebreek word dat mense ' $n$ sins- en betekeniskrisis beleef. Price erken dus dat godsdiens besig is om te ontwikkel, en reken dat ' $n$ mens nie pluralisme, sekularisasie en sinkretisme kan omkeer om weer by ' $n$ premoderne Bybelse wêreldbeeld uit te kom nie. Hoewel hy nie 'n sinkretistiese New Age-wêreldgodsdiens voorsien nie, maar tóg intergodsdienstige wisselwerking aanvaar, meen hy dat predikante se rol na dié van terapeute, beraders, maatskaplike werkers en motiveringsprekers sal verander. Price (2003:7) roep predikante op om die veranderde omstandighede wat die postmoderne wêreld meegebring het meer entoesiasties te aanvaar. Hy stel dit soos volg:

'They will be shepherds of their flocks, as they ought to be, and it will be left to scholars, theologians and historians of religions to serve as consultants, providers of insight, and lessons from history.'

Don Cupitt (2000:3) van die Emmanuel College in Cambridge, en die stigter van die Sea of Faith-netwerk, beskryf drie duidelike tekens van die snelle agteruitgang van godsdiens deur die wêreld heen, maar veral in die Weste:

- Die eerste teken is dat kommentators beweer dat die toekoms van die mensdom van tegnologie en die logika van kapitalisme afhang. Teologie, filosofie, etiek en politiek het reeds gesterf, en sal dus randfigure bly.

- 'n Tweede teken is dat die hoofstroom- Christelike kerkgroepe 'n 20\%-verlies aan lidmate per dekade toon.

- Derdens het ' $n$ opname onder 18 -jariges getoon dat $77 \%$ van die tieners geen godsdienstige belange of bande het nie.

Cupitt (2000:4) voer as rede vir dié verval aan dat die kerk 'n flater begaan het:

In effect, the church made an idol of itself, and is now dying because it stuck with claims on its own behalf that it should never have made in the first place.'

Volgens hom het godsdiens nou ' $n$ ander rol te speel:

At a time when political thought is very unadventurous, and when the world is becoming overwhelmingly dominated by technology, 
we need religion as much as ever. We need it as a human, value creating activity.

(Cupitt 2000:9)

Volgens Marcus Borg (2006:vii), 'n dosent in Godsdiens en Kultuur aan die Oregon-staatsuniversiteit, is daar Christene wat nie meer soos hulle voorouers glo nie. Hy noem dié groep die ontluikende ('emerging') Christene wat van binne én buite die kerk ander beskouings as die tradisionele teologie ontwikkel het. Hulle skakel die intellektuele struikelblokke van die Bybel as onfeilbare goddelike produk uit. Vir hulle is die Bybel ' $n$ bewys van voorouers se geloof en hulle ervarings van God. Borg (2006:viii) skryf soos volg in die voorwoord van Tim Scorer se boek, Living the Heart of Christianity: A guide to putting your faith into action:

And rather than emphasizing what we must do or believe in order to have a blessed afterlife, the emerging Christian vision emphasizes a relationship with God in the present that transforms our lives in this life.

(Borg \& Scorer 2006)

Borg beweeg derhalwe ook op die postmoderne vlak, en het ' $n$ panenteïstiese begrip van God. Die Suid-Afrikaanse praktiese teoloog Yolanda Dreyer (2006:1311-1335) van die Universiteit van Pretoria ondersoek postmoderne kerkwees in die lig van die publieke teologie, eenheid en verskeidenheid. Dreyer (2006:1317-1324) verlaat haar op Burkhard om die vyf kenmerke van postmoderniteit te bespreek, maar brei dan ook aansienlik daarop uit:

- Postmoderniteit verwerp 'n dualistiese wêreldbeeld. Moderniteit het tussen die natuurwetenskap en die subjektiewe sfeer van gevoelens, verbeelding, waardes en geloof onderskei, en die subjektiewe onderdruk. Postmoderniteit kritiseer dié skeiding.

- Postmoderniteit verwerp fondamentalisme: Burkhard (2004:132, in Dreyer 2006) beskryf fondamentalisme soos volg: 'Foundationalism refers to absolutely irreducible principles of knowledge and action whose truth imposes itself with irrefutable evidentiary power.'

- Postmoderniteit verwerp totalisering: Moderniteit wou een algemene denkstelsel ontwikkel wat vir almal geld, en die hoofnarratief van onbeperkte menslike vooruitgang het vooropgestaan. Postmoderniteit verwerp so ' $\mathrm{n}$ allesoorheersende teorie.

- Die bedreiging van nihilisme bestaan wél: As niks in 'n postmoderne wêreld geld nie, ontstaan die vrees dat alles relatief is, wat op sy beurt nihilisme tot gevolg het. Tog is dít nie wat postmoderniteit met pluraliteit in gedagte het nie. Dreyer (2006:1320) reken dat dit juis die geleentheid vir die Christelike verhaal en die verhale van nihilisme is om met mekaar in gesprek te tree.

- Postmoderniteit soek na verwantskappe: Postmoderniteit plaas die klem op die mens in verhouding tot alles, in plaas daarvan dat die mens as subjek sentraal staan. 'Kennis word verkry deur mense wat saamwerk, eerder as die individuele kenner' (Dreyer 2006:1320).

Dreyer (2006:1331) verwelkom postmoderniteit omdat die Christen se stem tussen al die ander stemme gehoor kan word, maar wel op die volgende voorwaarde: 'Pluraliteit in die kerk kan positief gewaardeer word, maar behoort ook teologies duidelik begrens te word.' In die publieke teologie kan die kerk nou aan ander waardestelsels gelyk wees - nie deur konfrontasie nie, maar deur dialoog. Dreyer verwoord dié verhoudingsgedagte soos volg (2006:1321): 'Mens-wees met ander en in teenwoordigheid van God kan mense van hierdie era bevry van die leegheid waarmee moderne denke hulle gelaat het.'

Die Jesus Seminaar-teoloë wou, in die lig van hulle navorsing oor die historiese Jesus, en die kerk se reaksie daarop, die huidige stand van die Christelike tradisie in oënskou neem. In The future of the Christian tradition: The Jesus Seminar (Miller 2007) ondersoek die teoloë die egtheid van huidige geloof, wysheid vir die globale era, godsdiens, wetenskap, en die toekoms van die lewe op aarde, sowel as die morele noodsaak. Hulle erken ook die ontwikkeling van geloof, en in sy artikel 'Beyond theism but not beyond God' erken John Shelby Spong (2007:35) dat hy ' $\mathrm{n}$ Christen van die $21^{\mathrm{e}}$ eeu is, en daarom '... Ii]f my Christianity cannot live inside the thought forms of the twenty first century, then I do not believe it can live at all.' Hiermee probeer hy nie te kenne gee dat die $21^{\mathrm{e}}$ eeu die toppunt van wysheid en waarheid verteenwoordig nie, maar dat dit ook iets vir sy geloof moet beteken. Spong (2007:40) worstel met die Godsbegrip, en sê:

When I seek the God beyond theism, I seek to name a human experience of wonder, awe and transcendence....

Spong (2007:40)

Later voer hy ook soos volg aan (2007:44):

Christianity is entering the transcendent depth of life, love and being in a human experience with a man named Jesus of Nazareth and calling that experience God.

God is nie ' $n$ teïstiese wese of ' $n$ menslike konstruksie nie, maar wel ' $n$ volledige begrip van die diepste wese van die mens. Spong verwoord dit soos volg:

It is about a humanity that has been opened to divinity. It is about stepping into eternity while still walking in time...If God is the ground of all being then the only way I can worship God is to have the courage to be all that I can be.

(Spong 2007:44, 45)

Op sy beurt praat Gerrit Immink (2003) In God geloven: Een praktisch-theologische reconstructie van geloofskommunikasie dat sowel God as mense wil praat en luister - en stel Immink voor dat dít die kern van godsdiensbeoefening word. God bly die 'Gans Andere' waarmee die mens nooit een kan word nie. Nóg 'n gewilde alternatief is om alle vorme van premoderne godsdiens as ' $n$ moontlike model vir 'n postmoderne wêreld te verwerp. So verwerp Sam Harris (2004/6) The end of faith: Religion, terror, an the future of reason byvoorbeeld die mitologiese godsdiens, en kritiseer dit as 'gif en vernietiger' van die samelewing. Harris beskou egter die mistieke as die enigste rasionele opsie vir die transformasie van die bewussyn:

Mysticism is a rational enterprise. Religion is not. The mystic has recognized something about the nature of consciousness prior to thought, and this recognition is susceptible to rational discussion. The mystic has reason for what he believes, and these reasons are empirical.

(Harris 2004:221)

In sy kritiek op Harris se voormelde werk verwerp Joe BesslerNorthcutt (2005:21) Harris se argumente oor godsdiens omdat hy glo dié omstrede outeur

...simplistically evacuates any sense of integrity to a moderate or liberal religious stance. He does this in order to create an urgent sense of either/or, to force a choice between faith and reason.

$\mathrm{Al}$ wat Bessler-Northcutt ter verdediging kan aanbied, is die Jesus Seminaar as ' $n$ rasionele oefening deur Bybelse teoloë. Hy sien nie eens Harris se mistieke betoog raak nie.

Aan die ander kant skerm die tradisionele Christene hulleself teen sekularisasie af en probeer dit beveg. Die woord 'sekularisasie' is aanvanklik vir die vervreemding van kerklike eiendomme gebruik (Weiland 1972:21), maar begin later na ' $n$ samelewing verwys wat ál minder die invloed van kerklike gesag en voorskrifte aanvaar (kyk O'Collins \& Farrugia 2000:239). Sperna Weiland het reeds in 1966 die wortels van sekularisasie in die Vulgaatvertaling van sekere kern Bybeltekste gaan soek (Weiland 1972). Hy ondersoek ook hoe sosioloë, filosoween teoloë dit omskryf. Een omskrywing lui soos volg: 'De secularisatie is dus de afscheid van een wereld, waarin de kerk op alle terreinen van het laaste woord heeft' (Weiland 1972:22). Die kerk het dus nie meer die rigtinggewende invloed in ' $\mathrm{n}$ gesekulariseerde samelewing nie, en volgens Weiland $(1972: 17,18)$ het Friederich Gogarten en Dietrich Bonhoeffer dit onderskeidelik as ' $n$ goeie ding beskou: Gogarten meen sekularisasie dui onder andere op die selfstandigwording van die mens, wat 'n regstreekse gevolg 
is van die evangelieverkondiging en veral die herontdekking van die evangelie deur die Reformatore. Dietrich Bonhoeffer praat van die mondigwording van die mens om sinvol in die wêreld te kan bestaan. Die sienings dat sekularisasie beveg of verwelkom moet word, spruit uit die institusionele kerk se ontwikkelingsvlak, en sal verskillende invloede op die pastoraat hê.

Die vinnige ontwikkelingspas van tegnologie, ekonomie en politiek laat baie Christene en die institusionele kerk met 'n ontoereikende epistemologiese selfbeeld. Die huidige postmoderne gesekulariseerde kultuur verskil radikaal van die tradisionele godsdienstige kaart waarmee baie Afrikaanse Christene deur hierdie vreemde landskap moet reis. Christene voel vervreemd in die gesekulariseerde samelewing, en tog voer Edward Norman (2003:44) aan dat die meeste Christene onbewus is van hoe gesekulariseerd hulle alledaagse lewens werklik is. Norman beskuldig die Anglikaanse kerkleiers in Engeland daarvan dat hulle verantwoordelik is vir die indra van sekulêre humanisme as die kernboodskap van die kerk.

It is not the general secularization as such which has felled it, but the adoption by the Church of secular thought - death by one's own hand.

(Norman 2003:x)

Of sekularisasie die tradisionele Afrikaanse kerke al só diep binnegedring het, is onuitgemaak. Tog is daar sommige Christen teoloë en -leke wat die Jesus Seminaar se siening van die historiese Jesus as aanslag teen die heiligheid van die kerklike tradisie beskou. Gedurende 2007 het 'n DVD-dokumentêr getiteld 'Nuwe strominge in die teologie: Word die hart van die evangelie uitgeruk?' deur WTL Multimedia Produksies, wat aan predikante van die Nederduitse Gereformeerde Kerk en die Nederduitsch Hervormde Kerk gestuur is, geweldige reaksie ontlok. Onder andere het dr Chris Saayman die volgende uitspraak gemaak:

Die inhoud van hierdie dokumentêr is - om dit sag te stel skrikwekkend omdat dit openlik lasterlik is. Hier het ons nie meer net te make met sekere afwykings van die gereformeerde belydenis nie, maar met blatante kettery. Prontuit word ontken dat die Bybel God se Woord is. Daar word gesê dat Jesus se versoeningsdood aanstootlik is, dat sy maagdelike geboorte fiksie is, dat Sy opstanding "metafories" is ensovoorts. Die gnostiese kettery van die eerste eeue word openlik as die outentieke Christelike geloof aangeprys - in direkte stryd met Johannes se eerste sendbrief wat die gnostisisme as die "gees van die antichris" beskryf. Wat oorbly is niks anders nie as ' $n$ stuk heidendom waarin daar geen spoor van die Christelike Geloof meer te vinde is nie. Ja, sekere Bybelse terme word gebruik, maar met ' $n$ onbybelse inhoud gevul.

(Saayman 2007)

Hoewel hierdie betoog nie wetenskaplik is nie, blyk dit dat daar wel Christene is wat dié soort bedreiging van binne ervaar. Tog is dit nie só eenvoudig nie. Kerklike teïsme en postmoderne teologie is slegs twee fases of vlakke in die ontwikkeling van die menslike bewussyn of geloof. James W. Fowler, 'n toegewyde Christen sosioloog, het reeds in die sewentigerjare navorsing oor die ontwikkeling van geloof gedoen, en het ses geloofsfases uitgewys (wat die babafase uitsluit). In Stages of faith: The psychology of human development and the quest for meaning bied Fowler (1995:xiii) 'n teorie oor geloofsgroei aan: 'At the heart of the book you will find an account of a theory of seven stagelike, developmentally related styles of faith that we have identified.' Hy noem die fases van geloof 'intuitive-projective (magical), mythicliteral, syncretistic-conventional, individuative-reflective, conjunctive en universalising faith'. Op die gebied van Ontwikkelingpsigologie en Integrale Psigologie is navorsing oor die ontwikkeling van menslike bewussyn ook reeds lank aan die gang.

Brant Cortright, 'n professor in Psigologie en direkteur van die Integral Counseling Psychology-program van die California Institute of Integral Studies, wys daarop dat die lewe 'n geestelike avontuur is:
The goal is to wake up to our deeper identity so we can align with this larger, Divine movement of love and delight. Life is a spiritual adventure in the evolution of consciousness. Spiritual embodiment is the goal, not a disembodied transcendence. For this we need to discover our soul, our psychic centre, which is the evolutionary principle in us.

(Cortright 2007:4)

Cortright (2007:1) laat skakel dus Westerse en Oosterse psigologie by mekaar in om die uiterlike navorsing van die Weste en die innerlike studie van die Ooste te kombineer, en sodoende ' $n$ geïntegreerde psigologie daar te stel. Integrerende Psigologie beskou die lewe as die goddelike ontvouing van, en die grondslag vir, die goddelike bewussyn. Bewussyn is nie uit die staanspoor volgroeid nie, maar ontwikkel mettertyd.

\section{STATE VAN MENSLIKE BEWUSSYN}

Die uiteindelike doel van die ontwikkeling van menslike bewussyn is om op die hoogste vlak van die eenheid van die mens se siel met God bewus te word. Ken Wilber, wat deur Westerse én Oosterse denkers beïnvloed is, se ontwikkelingsteorie is die mees geïntegreerde teorie wat tans bestaan. Volgens Wilber kom die volledigste bewuswording van die eenheid van die siel met God op die mistieke ontwikkelingsvlakke voor. Kortliks bestaan Wilber se ontwikkelingsteorie, oftewel AQAL ('All Quadrants, All Levels and All Lines'), uit sowel die innerlike as die uiterlike; uit sowel enkelvoud- as meervoudsperspektiewe; en ook al die ontwikkelingsvlakke en state van menslike bewussyn.

Die vraag hoe Christene pastoraal begelei kan word om sinvol en gelowig in 'n sekulêre wêreld te leef, kan aan die hand van Ken Wilber se AQAL-teorie beantwoord word. Wilber se integrale ontwikkelingsteorie kan vir die kerklike pastoraat van nut wees om die ontwikkelingsfase op ' $n$ geïntegreerde manier van sowel binne as buite te verwerk. Soos reeds aangedui, staan AQAL in Wilber (2006:26) se eie woorde vir 'all quadrants, all levels, all lines, all states, all types'. Die kern van Wilber se integrale teorie is dat menslike bewussyn en perspektiewe ontwikkel van die argaïese na die magiese vlak, wat albei egosentries is; daarna na die mitologiese vlak, wat op sy beurt etnosentries is; en dan na die rasionele en pluralistiese vlakke, wat wêreldsentries is. Die tweede ontwikkelingslaag, of mistieke ontwikkeling, wat van die integrale tot die transpersoonlike vlak en verder strek, is kosmosentries, en sluit dus alles in. (Wanneer Wilber die woord 'Kosmos' gebruik, sluit hy ook siel en Gees daarby in.)

Alle mense begin by die argaïese, en vorder so ver hulle wil of kan. In A sociable God: Towards a new understanding of religion noem Wilber (2005:98-102) nege gebruike van die woord 'godsdiens', waarvan die laaste twee $(2005: 101,102)$ 'legitieme' en 'outentieke' godsdiens is. Legitieme godsdiens verkondig mites, en help mense om taboes te vermy. Outentieke godsdiens begelei mense om te transformeer, en vergesel hulle op die ontwikkelingspad. In Sex, ecology, spirituality verdeel Wilber (2000:197-198) die begrip van die werklikheid in kwadrante met ' $n$ innerlike en ' $n$ uiterlike, 'n enkelvoud en 'n meervoud, wat die skone, die goeie en die waarheid; kuns, moraliteit en wetenskap; oftewel, die ek, die ons en die dit/ditte verteenwoordig. Van uiterste belang is die verskillende state van menslike bewussyn: Wakker, droom en diep slaap is die drie bekendes. Volgens Wilber is daar ook ander state/vorme van bewussyn:

Meditative states (induced by yoga, contemplative prayer, meditation and so on), altered states (such as drug-induced) and a variety of peak experiences, many of which can be triggered by intense experiences like making love, walking in nature, or listening to exquisite music.

(Wilber 2006:4)

Hierdie state van menslike bewussyn kan op enige van die ontwikkelingsvlakke ervaar word en kan help om vinniger van een vlak na die volgende te ontwikkel. Wilber $(2006: 10,11)$ wys egter op die volgende: '... you cannot have a peak experience of a higher stage (like being a concert-level pianist), because stages unfold sequentially and take considerable time to develop.' Volgens Reynolds (2004:206) het Wilber ook verskillende ontwikkelingslyne, -golwe 
of -strome uitgewys, naamlik 'n kognitiewe, selfidentiteitwaarde-, morele, estetiese, spirituele, behoefte-, psigoseksuele, emosionele en interpersoonlike lyn. Andre Marquis (2008) brei soos volg daarop uit en koppel boonop aan elke lyn 'n lewensvraag, met tussen hakies die name van die ondersoekers wat oor die betrokke lyn navorsing gedoen het (Marquis 2008:105; vgl Wilber 2006:60):

- Kognitief - Waarvan is ek bewus? (Piaget, Kegan, Vygotsky)

- Self - Met watter van die dinge waarvan ek bewus is, vereenselwig ek my? (Loevinger, Cook-Greuter)

- Waardes - Watter van die dinge waarvan ek bewus is, is vir my die waardevolste? (Graves, Beck en Cowan)

- Moraliteit - Watter van die dinge waarvan ek bewus is, behoort ek te doen? (Kohlberg, Gilligan)

- Estetika - Watter van die dinge waarvan ek bewus is, is vir my die mooiste? (Housen)

- Spiritueel - Watter van die dinge waarvan ek bewus is, is die grondslag van my lewe? (Fowler, Tillich)

- Behoeftes - Watter van die dinge waarvan ek bewus is, het ek nodig? (Maslow)

- Kinesteties - Hoe behoort ek dit fisies te doen? (Gardner)

- Emosioneel - Hoe voel ek oor die dinge waarvan ek bewus is? (Salovey, Meyer, Solomon, Goleman)

- Interpersoonlik - Hoe behoort ek op grond van die dinge waarvan ek bewus is sosiaal teenoor ander op te tree? (Selman, Perry)

Hierdie lyne funksioneer en ontwikkel betreklik onafhanklik, maar dit die Absolute Self wat die ontwikkelingslyne bymekaar hou. Soos reeds aangetoon, konsentreer Nolte (2007:17) uitsluitlik op die emosionele-intelligensielyn sonder om die ander ontwikkelingslyne te vermeld. Wilber (2006:192-200) wys daarop dat godsdiens by uitstek die vervoerband vir die mensdom en sy verskillende groeistadia is, en voer die volgende twee belangrike redes vir sy stelling aan:

The first is that the world's religions are the repository of the great myths. The early stages of development are archaic and magic and mythic in flavor. And these great myths, laid down 3000 years ago, could never be created today, not because humanity has no imagination, but because everybody has a video camera. Iust let Moses try to claim he parted the Red Sea and see how far he gets... The mythic-stages of the religious systems speak deeply to these stages of development, and, to repeat, THOSE STAGES ARE NOT GOING AWAY. Everybody is born at square one.

Precisely because they got their start with the (archaic, magic and mythic) stages of humanity itself, they control the legitimacy conferred on those beliefs. Because of that, they are the only sources of authority that can sanction the (rational and higher) stages of spiritual intelligence in their own traditions. They are the only systems in the world today that can act as a great conveyer belt, helping people move from the lower to the higher stages, because they alone can pronounce all of those stages kosher, legitimate, sacred, acceptable - and give them imprimatur within their own lineages.

(Wilber 2006:192, 193)

Die belangrikste rol wat godsdiens in die moderne en postmoderne wêreld kan speel, is moontlik om as ' $n$ heilige vervoerband vir die mensdom op te tree. Wilber (2006:196) stel dit baie duidelik dat hoe gouer godsdienste begin om hoër vlakke en hoër state te bied, hoe gouer sal godsdienste dié nuwe rol in die moderne en postmoderne wêreld kan vervul. Volgens Wilber is daar egter nóg ' $\mathrm{n}$ rede waarom godsdienste as vervoerband vir die mensdom meditasie, oorpeinsing en ongewone state van bewussyn by hulle kurrikula moet insluit:

... that is not just to stop forcing kids into raves and grown adults into tent revivals, but for the profoundly beneficial effect that states have on stages...[T]he more you experience various states, the more quickly you develop through the stages.

(Wilber 2006:196)

\section{‘N OUTOBIOGRAFIESE REIS}

My spirituele reis het reeds vroeg tuis begin. My pa was ' $\mathrm{n}$ denker wat dinge bevraagteken het en verby die kerklike dogma gekyk het om 'n lewende verhouding met God te hê. Hy het ons as gesin aan teologiese beredenerings en andersdenkendes blootgestel. My eerste piekervaring ('peak experience') was in matriek toe ek en 'n vriend Durban toe geryloop het. Op die strand, ons vakansieslaapplek, het ons met interessante karakters kennis gemaak, en daar het ek 'n helder oomblik gehad. Ek wou iets doen om betekenis aan my lewe te gee. Ná die ervaring het ek geweet dat ek Teologie moes studeer om die evangelie aan ambagspersone oor te dra. Hierdie piekervaring was geheel en al op die fundamentalisties-mitologiese ontwikkelingsvlak. In die eerste drie maande aan die Universiteit van Johannesburg (destyds die Randse Afrikaanse Universiteit) het die wetenskap my fundamentalistiese agtergrond blootgelê. Dit was ' $n$ ongemaklike ervaring. Nadat my oë vir die rasionele sy van geloof oopgegaan het, het dinge duideliker begin geword. Hierna het ek my teologiese studie aan die Universiteit van Pretoria begin. Dit het my voor ' $n$ geloofskrisis te staan gebring. Ek moes die kerklike (mitiese), dogmatiese windmeulens met die rasionele lans stormloop. My BD-skripsie getiteld ' $n$ Voorlopige ondersoek na 'n Christelike waardering van die Afrikaanse letterkunde sedert die Sestigs' was op 'n Christelike begrip van Afrikaanse letterkunde sedert die sestigerjare gerig. Ek het deel van my 'roeping' voltooi.

Die gemeentebediening was frustrerend omdat ek verder wou beweeg, maar die lidmate nie vir die ontwikkeling gereed was nie - Nolte se 'kognitiewe dissonansie' My predikantsloopbaan is opgevolg deur 13 jaar as regisseur van godsdienstige televisieprogramme aan die destydse Suid-Afrikaanse Uitsaaikorporasie. Dit het my aan ' $n$ verskeidenheid sienings en godsdienste blootgestel. Daar het ek meer direk met kunstenaars saamgewerk. Ek noem dit my 'pluralistiese fase'. Ek het baie in die ontwikkeling van die mens belang gestel, maar was nog nie heeltemal gereed vir die mistieke nie. Gedurende my sewe werklose jare het ek Sallie McFague (1982; 1987; 1993; 1997; 2001) se oeuvre verslind wat my gehelp het om die pluralistiese fase te bemeester. Haar metaforiese teologie het my laat besef dat alle godsdienste verskeie metafore van God aanbid, en dat elkeen op sy unieke manier die pad na God vind. Wanneer hierdie artikel dus metafore of terme vir God, soos Brahmaan, gebruik, is dit net ' $n$ ander term vir God, en nie ' $n$ ander God nie, want daar is net een Grondwese van alle bestaan. Hoekom kon ek dit nie eerder in die Teologie of die kerk besef nie? Dis ook in dié tyd dat ek Ken Wilber se werk ontdek het, en vir die eerste keer ' $n$ geheelbeeld gekry het.

Gedurende dié tyd het ek 'n reeks artikels oor spoorsny vir die tydskrif Country Life geskryf, en dit was juis op een van hierdie spoorsnytogte dat ek my volgende piekervaring gehad het. Ek en die veldwagter/spoorsnyer, Colin Patrick, het na njalaspore gesoek toe ons op luiperdspore afkom. Colin het voor gestap en gesê dat wanneer ' $n$ mens spoorsny jy een met die dier moet word wie se spoor jy volg. Toe ons die luiperdspore sien, was ek nie een met die luiperd nie, maar een met die njala, volkome waaksaam, gereed om op die vlug te slaan. Ek het die geringste geluid en beweging waargeneem, en was gereed vir enige gebeurlikheid. Die ervaring het nie lank geduur nie, net lank genoeg om te weet wat dit beteken om een met die natuur te wees. Hierdie natuurervaring was nog nie heeltemal ' $n$ mistieke ervaring nie, maar wel eenwording met die natuur op rasionele vlak. Tog het dit die deur na die mistieke op 'n skrefie oopgemaak. Omdat ek egter in daardie stadium nog nie genoeg van die mistieke geweet het nie, was dit ' $n$ vlietende oomblik, en aangesien ek nie daaroor gemediteer het en niemand gehad het om my te begelei nie, bly die oomblik net ' $n$ vae dog goeie herinnering.

Kognitief begryp ek die tweede ontwikkelingslaag, oftewel die mistieke vlakke, beter as destyds, maar spiritueel het ek nog nie een met dié vlakke geword nie. Streng geestelike dissipline is nodig om van die eerste laag na die mistieke te vorder, en ek mediteer nog maar net die afgelope vyf jaar. Die groeiproses is 
nie maklik nie, veral as jy nie weet wat aan die gebeur is nie. In sy beroemde gedig noem sint Johannes van die Kruis dit 'die donker nag van die siel'. Hoewel my ontwikkeling nog nie voltooi is nie, het ek die innerlike drang om ander mense die pyn te spaar, en hulle op die pad van geloofsontwikkeling te probeer begelei. Die kerk is die ideale weg om alle gelowiges op hierdie pad te ondersteun.

\section{BEVINDING}

Uit dié artikel blyk dit dus dat daar Christene is wat aan die een kant sekularisasie uit die tradisionele kerklike perspektief wantrou, terwyl sommige aan die ander kant reeds verby die tradisionele na die postmoderne perspektief beweeg het. Albei hierdie standpunte is paradigmas of ' $n$ begrip van die werklikheid uit ' $n$ bepaalde hoek. Hierdie studie stem saam met die integrale filosoof Steve McIntosh wat die onderskeid tussen opvattings en perspektiewe soos volg verwoord:

Although every perception is always already a perspective, although humans can never perceive things as they really are, a given perspective can be relatively more or less powerful depending on the degree of reality that it apprehends. And the one test of the relative degree of a given perception's grasp of reality is its ability to improve the human condition.

(McIntosh 2007:211)

Die uitdaging vir sowel tradisionele as postmoderne teoloë is om uiteindelik die ontwikkeling van die menslike bewussyn te bewerkstellig - dit te midde van (en ondanks) opvattings en persoektiewe, wat op hulle beurt hopelik voortdurend verander en verbeter. Wat dus nodig is, is ' $\mathrm{n}$ studie wat die ontwikkelingsvlakke en -kwadrante uit verskeie hoeke ontleed, en elkeen se begrip van die psige/siel/self bestudeer, om die pastoraat as heilige vervoerband by te staan om tot die volledige of integrale ontwikkeling van gelowiges by te dra. In 'n opvolgartikel sal daar op invloedryke psigologiese teorieë oor die menslike bewussyn gekonsentreer word.

\section{LITERATUURVERWYSINGS}

Avis, P., 2003, A church drawing near: Spirituality and mission in a post-Christian culture, T \& T Clark, Londen.

Berger, P.L., 2004, Questions of faith: A skeptical affirmation of Christianity, Blackwell, Cornwall.

Bessler-Northcutt, J., 2005, 'Religion: Mend it, don't end it', The Fourth $R$ 18(6), 21

Borg, M., 2006, Jesus: Uncovering the life, teachings and relevance of a religious revolutionary, HarperCollins, New York.

Borg, M. \& Scorer, T., 2006, Living the Heart of Christianity: A Guide to Putting Your Faith into Action, HarperCollins, New York.

Cortright, B., 2007, Integral psychology: Yoga, growth, and opening the heart, State University of New York Press, Albany.

Cupitt, D., 2000, 'Christianity after the church', The Fourth $R$ 13(6), 3-9.

Dreyer, Y., 2006, 'Postmoderne kerkwees in die lig van publieke teologie - eenheid en verskeidenheid', HTS Teologiese Studies/ Theological Studies 62(4), 1311-1335.

Dziuban, P.F., 2006, Consciousness is all: Now life is completely new, Blue Dolphin Publishing, Nevada City.

Fowler, J.W., [1981] 1995, Stages of faith: The psychology of human development and the quest for meaning, HarperCollins, New York.

Harris, S., 2006, The end of faith: Religion, terror, and the future of reason, Simon \& Schuster, Londen.

Immink, F.G., 2003, In God geloven: Een praktisch-theologische reconstructie, Meinema, Zoetermeer.

Keller, C., 2008, On the mystery: Discerning God in process, Fortress Press, Minneapolis.

Leaves, N., 2006, The God problem: Alternatives to fundamentalism, Polebridge, Santa Rosa.

Marquis, A., 2008, The integral intake: A guide to comprehensive idiographic assessment in integral psychotherapy, Routledge, New York.
McFague, S., 1982, Metaphorical theology: Models of God in religious language, Fortress Press, Philadelphia.

McFague, S., 1987, Models of God; Theology for an ecological, nuclear age, Fortress Press, Philadelphia.

McFague, S., 1993, The body of God: An ecological theology, Fortress Press Minneapolis, Minnesota.

McFague, S., 1997, Super, natural Christians: How we should love nature, Fortress Press, Minneapolis.

McFague, S., 2001, Life abundant: Rethinking theology and economy for a planet in peril, Fortress Press, Minneapolis.

McIntosh, S., 2007, Integral consciousness and the future of evolution: How the integralworldview is transforming politics, culture and spirituality, Paragon House St Paul, Minneapolis.

Miller, R.J. (red.), 2007, The future of the Christian tradition: The Jesus Seminar, Polebridge, Santa Rosa.

Nolte, S.P., 2007, 'Pastors as gewonde genesers: Emosionele intelligensie en pastoraat', PhD-proefskrif, Universiteit van Pretoria, Pretoria.

Norman, E., 2003, Secularization: Sacred values in a godless world, Continuum, Londen.

O'Collins, G. \& Farrugia, E.G., 2000, A concise dictionary of theology, T \& T Clark, Edinburgh.

Price, R., 2003, 'The future of religion', The Fourth R 16(1), 3-8.

Reynolds, R., 2004, Embracing reality: The integral vision of Ken Wilber, Penguin, New York.

Riggs, J.W., 2003, Postmodern Christianity: Doing theology in the contemporary world, Trinity Press International Harrisburg, Pennsilvanië.

Saayman, C., 2007, 'Word die Hart van die Evangelie uitgeruk?', in Bibleforums.org., besigtig 24 July 2007, van http://www. bibleforums.org/forums/forumdisplay.php.

Spong, S., 2007, 'The future of the Christian tradition: The Jesus Seminar', in R.J. Miller (red.), Polebridge, Santa Rosa, Kalifornië.

Weiland, J.D., 1972, Orientatie: Nieuwe wegen in de theologie, Het Wereldvenster, Baarn

Wilber, K., 2000, 'Sex, ecology, spirituality', in The collected works of Ken Wilber, vol. 6, Shambhala, Boston.

Wilber, K., 2005, A sociable God: Towards a new understanding of religion, Shambhala, Boston.

Wilber, K., 2006, Integral spirituality: A startling new role for religion in the modern and postmodern world, Integral Books, Boston.

Wilber, K., Patten, T., Leonard, A. \& Morelli, M., 2008, Integral life practice: The 21st century blueprint for physical health, emotional balance, mental clarity, and spiritual awakening, Integral Books, Boston. 